\title{
Atık Döküm Kumları İçin Uygun Bertaraf Yönteminin Maliyet Analizi ile Belirlenmesi: Bursa Örneği
}

\author{
Melike Yalılı Kılıç ${ }^{1, *}$, Murat Tüylü1 (i) \\ ${ }^{1}$ Uludağ Üniversitesi, Mühendislik Fakültesi, Çevre Mühendisliği Bölümü, 16059, Nilüfer, Bursa.

\section{Özet}

Türkiye'nin büyük ilk 500 sanayi kuruluşu içinde yer alan dökümhaneler, üretim prosesi sonrasında atık döküm kumlarının sürekli oluştuğu sektörlerdendir. Ekonomik değeri olan atık döküm kumları ülkemiz koşullarında yeterince değerlendirilemediğinden, fabrika alanlarında biriktirilmekte ya da düzenli depolama sahalarına gönderilerek geri kazanım sürecine dahil edilemeden heba edilmektedir. Oysaki genelde tehlikesiz türde olan atık döküm kumları, uygun şekilde yönetildiklerinde asfalt üretiminde agrega yerine alternatif hammadde olarak kullanılabilmektedir. Bu çalışmada, Bursa ili Nilüfer ilçesinde yer alan 46.200 ton üretim kapasiteli bir dökümhaneden kaynaklanan atık döküm kumlarının direkt düzenli depolama sahasında bertaraf edilmesi yerine, çimento fabrikası ve asfalt plent tesisine gönderilerek geri kazanılması ve alternatif hammadde olarak kullanılmasının çevresel ve ekonomik değerlendirilmesi yapılmıştır. Atık döküm kumlarının nakliye dahil olmak üzere düzenli depolama sahasına gönderilmesi durumunda 851.989 TL (163.844 \$), çimento fabrikasina gönderilmesi durumunda 1.097 .620 TL (211.081 \$) ve asfalt plent tesislerine gönderilmesi durumunda ise 35.431 TL $(6.814$ \$) bertaraf maliyetinin olacağı hesaplamalar sonucunda bulunmuștur. Dökümhane için en ekonomik yöntemin asfalt plent tesisi olduğu belirlenmiş olup, bertaraf maliyetlerinin en aza indirilmesi ile atık döküm kumlarının üretildikleri yere en yakın ve en uygun tesise en hızlı şekilde gönderilerek hava, su ve toprak kirliliğine neden olan fabrika sahalarındaki uzun süre depolamaların önleneceği düşünülmektedir.

\section{Anahtar Sözcükler}

Atık Döküm Kumu, Bursa, Dökümhane, Asfalt Plent Tesisi, Maliyet

\section{Determination of Proper Disposal Method for Waste Casting Sands by Cost Analysis: Bursa Sample}

\begin{abstract}
Foundries located in Turkey's first major 500 industrial companies, are among the sectors where waste foundry sands continuously existed. Waste foundry sands have economic value, but they are being accumulated in the foundry areas or send to landfills without being included in the recovery process, due to not being evaluated enough in our country's conditions. However, waste foundry sands which are generally non-hazardous can be used as alternative raw material instead of aggregate in asphalt production when adequately managed. In this study, environmental and economic evaluation has been made for waste foundry sands from a foundry with a production capacity of 46.200 tons in Nilüfer, Bursa, which has been sent to landfill, cement factories and asphalt plant to be recycled or used as raw material instead of being sent directly for disposal. The cost of disposal, including the transportation of waste foundry sand to the landfill site is calculated at 851.989 TL (163.844 \$), in case it is sent to cement factory it is 1.097.620 TL (211.081 \$), and if it is sent to asphalt plant facilities, it costs 35.431 TL (6.814 \$). This study determined that the most economical method for the foundry is asphalt plant and that long-term storage in the foundry which causes air, water and soil pollution can be prevented by minimizing disposal costs and sending waste foundry sands to the nearest and the most appropriate facility.
\end{abstract}

$\underline{\text { Keywords }}$

Waste Casting Sand, Bursa, Foundry, Asphalt Plant, Cost

\section{Giriş}

Ülkemizde, hurda, metal ve ambalaj atıkları maddi değerlerinin yüksek olması nedeniyle belediyeler, lisanslı firmalar ya da sokak toplayıcıları tarafından toplanmakta ve geri kazanım sistemine dahil edilmektedir. Ancak, mermer üretim ve kesim işlemlerinden kaynaklanan mermer tozları, seramik ve vitrifiye üretimi sonrası 1skartaya çıkan seramik ve vitrifiye kırıkları, dökümhanelerden kaynaklanan atık döküm kumları gibi endüstriyel atıklar, geri kazanım süreci içinde yeterince değerlendirilememektedir. Atıkların bertaraf maliyetlerinin yüksek olması nedeniyle, çoğu atık üreticisi atıklarını çevre mevzuatında tanımlanan süreler içerisinde bertaraf tesislerine göndermek yerine fabrika sahaları içinde biriktirmeyi tercih ettiğinden, yapılan uygunsuz biriktirmeler zamanla su, toprak ve hava kirliliğine neden olmaktadır. 
Fabrika alanları içinde üstü açık ve yığma şeklinde biriktirilen atık döküm kumları, rüzgarlarla dağılarak havaya karışmakta ve uzak mesafelere taşınmaktadır. Yağmur suları ile yüzeysel akışa geçen atık döküm kumları yüzeysel ya da yeraltı sularına karışabilmektedir. Genellikle toprak zemin üzerinde yapılan biriktirmeler nedeniyle de toprakta toplam organik halojenler, toplam petrol hidrokarbonları, gümüş, arsenik, baryum, kadmiyum, kobalt, krom, bakır, cıva, nikel, kurşun, uranyum, vanadyum ve çinko (URL-1 2010) gibi özel kirlilik gösterge parametrelerine rastlanabilmektedir. Ülkemizde bu tür atıkların geri kazanım süreçleri içinde değerlendirilmemesi nedeniyle atıklar, atık üreticileri tarafından düzenli depolama tesislerinde bertaraf ettirilmekte ya da alternatif olarak çimento fabrikalarına gönderilmektedir. Atıkların geri dönüşüm ve geri kazanım süreci içinde değerlendirilmeden bertarafı, hem maddesel hem de enerji olarak ciddi kayıplar yaşanmasına neden olmaktadır (URL-2 2017).

Türkiye'nin büyük ilk 500 sanayi kuruluşu (URL-3 2017) içinde yer alan dökümhaneler, metal döküm üretimi sonrasında prosesin gereği olarak atık döküm kumlarının sürekli oluştuğu sektörlerdendir. Üretim prosesi içinde kalıplamada kullanılan döküm kumu, sistem içinde birkaç defa kullanıldıktan sonra atık halini almaktadır. Ülkelerin 2017 yılında yapmış oldukları metal döküm üretimlerine göre, Türkiye yıllık 2.155.000 ton metal döküm üretimi ile dünyada on birinci, Avrupa'da ise üçüncü sırada yer almaktadır (URL-4 2018). Döküm sektörü için Çevre ve Şehircilik Bakanlığı'nın yayımladığı Rehber Doküman'da, 1 ton metal döküm üretiminde 0.2-0.5 ton döküm atığı oluştuğu ve bu atıkların \%65 oranında atık döküm kumlarından kaynaklandığı belirtilmiştir (URL-5 2012). Amerika Birleşik Devletleri'nde (ABD) 6-10 milyon ton, Avrupa'da 4.5-6 milyon ton, Hindistan'da ise 1 milyon ton atık döküm kumu oluşurken (Khatib vd. 2013; URL-4 2018), ülkemizde ise yılda 490.000 ton atık döküm kumu oluştuğu hesaplamalarla bulunmuştur.

Bakış vd. (2006) atık döküm kumları üzerine yaptıkları çalışmada, atık döküm kumlarının kimyasal analizi sonucunda \%96.73 silisyum dioksit $\left(\mathrm{SiO}_{2}\right), \% 0.59$ alüminyum oksit $\left(\mathrm{Al}_{2} \mathrm{O}_{3}\right), \% 0.21$ demir (III) oksit $\left(\mathrm{Fe}_{2} \mathrm{O}_{3}\right)$ ve eser miktarda diğer bileşikleri içerdiğini belirtmişlerdir. Genellikle tehlikesiz türde olan atık döküm kumları uygun yönetildiklerinde, çevre için büyük bir tehlike oluşturmamaktadır. Dyer vd. (2018) atık döküm kumlarının yeterli koruyucu önlemler alınmadan fabrika sahalarında biriktirildiğini ve büyük fiziksel alanlar kapladığını, aslında bu alanların ekonomik ve sosyal amaçlar için kullanılabileceğini belirtmiştir. Ülkemizde dökümhanelerde oluşan atık döküm kumları geri kazanım ile çeşitli sektörlerde hammadde olarak kullanılabilecekken, ekonomik olarak değerli görülmemekte ve atık olarak bertaraf edilmek üzere düzenli depolama sahalarına gönderilmektedir. Atık döküm kumları, evsel nitelikli atıkların depolanması için kurulan II. sınıf düzenli depolama sahalarının kapasitelerini doldurmakta ve planlanandan daha kısa zamanda ömürlerinin tamamlanmasına neden olmaktadır.

Ulusal ve uluslararası literatürde atık döküm kumlarının karayolu malzemesi olarak kullanımının mümkün olduğu ve kaliteli bir kaplama malzemesi olarak kullanılabileceği (Gedik 2008), asfalt üretimine (Bakış vd. 2006; Dyer vd. 2018), ve çimento üretimine (Apay vd. 2011; Yazoghli-Marzouk vd. 2014) uygun olarak değerlendirilebileceği belirtilmektedir. Avrupa'da oluşan döküm kumlarının \%25-30 kadarı çimento endüstrisinde, tarım uygulamalarında ve bertaraf sahalarında değerlendirilmektedir (URL-4 2018).

Türkiye'de atık döküm kumları Çevre ve Şehircilik Bakanlığı tarafından yetki verilmiş düzenli depolama tesislerine bertaraf amacıyla ya da alternatif hammadde olarak çimento üretimi içinde kullanılmak üzere çimento fabrikalarına gönderilmektedir. Şehirlerde düzenli depolama tesisleri ve çimento fabrikalarının sayılarının az olması, sanayi ve üretim alanlarına olan mesafeleri, mesafeden kaynaklanan nakliye ücretlerinin maliyeti gibi nedenlerden dolayı atık döküm kumlarının bertarafı ya da hammadde olarak kullanımı sınırlı olarak gerçekleşmektedir. Otomotiv ve makine sektöründe faaliyet gösteren fabrikaların yoğunlukta olduğu Bursa ilinde, bu sektörlere hammadde olarak malzeme üreten büyük ve orta ölçekli 9 adet dökümhane bulunmaktadır. Bu dökümhanelerde oluşan atık döküm kumlarının gönderilebileceği düzenli depolama sahası, çimento fabrikası ve alternatif olarak asfalt plent tesisleri Şekil 1'de gösterilmiştir (URL-6 2018; URL-7 2018). Bursa ilinde bulunan dökümhaneler ile düzenli depolama sahası ve çimento fabrikası arasında uzak mesafeler bulunmakta olup, asfalt plent tesisleri ise bu dökümhanelerin etrafına konumlanmış olarak yer almaktadır.

Atık Yönetimi Yönetmeliği'ne göre atıkların üretildikleri yere en yakın ve en uygun tesise en hızlı şekilde ulaştırılarak, uygun yöntem ve teknolojiler kullanılarak işlenmesi esastır (URL-8 2015). Atık döküm kumlarının düzenli depolama sahaları veya çimento fabrikalarına taşınması yerine, oluştuğu yere yakın yerel çözümler içinde değerlendirilmesi, atıkların daha az taşınmasını ve yakın tesisler arasında endüstriyel simbiyoz ilişkisinin kurulmasını sağlayacaktır. Endüstriyel simbiyoz tercihen birbirine fiziksel olarak yakın olup, normalde birbirlerinden bağımsız çalışan iki veya daha fazla endüstriyel işletmenin bir araya gelerek hem çevresel performansı hem de rekabet gücünü artıracak uzun süreçli ortaklıklar kurması ve dayanışma içinde çalışması olarak tanımlanmaktadır. Endüstriyel simbiyoz yaklaşımı ekonomik kalkınma, yeşil büyüme ve kaynak verimliliği çabaları için stratejik bir politika aracı olarak görülmektedir. Yakın tarihli AB politika kaynakları, endüstriyel simbiyozu ekonomik ve çevresel politikanın bütünsel bir parçası olarak desteklemişlerdir (Çoban 2016). Yabancı ülkelerde yapılan çalışmalarda atık döküm kumlarının yol ve otoyol yapımı ile asfalt üretimi içinde kullanıldığı örneklere sıklıkla rastlanmaktadır. ABD’de Asphalt Paving Inc. (API) adlı asfalt üretim tesisine 2001 yılında 31.000 ton'dan fazla atık döküm kumu gönderilmiştir. ABD’nin Batı Virginia eyaletinde 2000 yılında 21.000 ton atık döküm kumu otopark inşaatında alt temel malzemesi olarak kullanılmıştır (URL-9 2002). 2016 yılı Temmuz ayında yapımına başlanan ve 30 Haziran 2019 tarihinde tamamlanması planlanan Madrid-Bilbao Yüksek Hızlı Tren inşaatının dolgu uygulamalarında ve akışkan harç hazırlanmasında Avrupa'da bulunan bir çelik dökümhanesinin atık döküm kumları \%60 oranında kullanılmaktadır (URL-4 2018). 


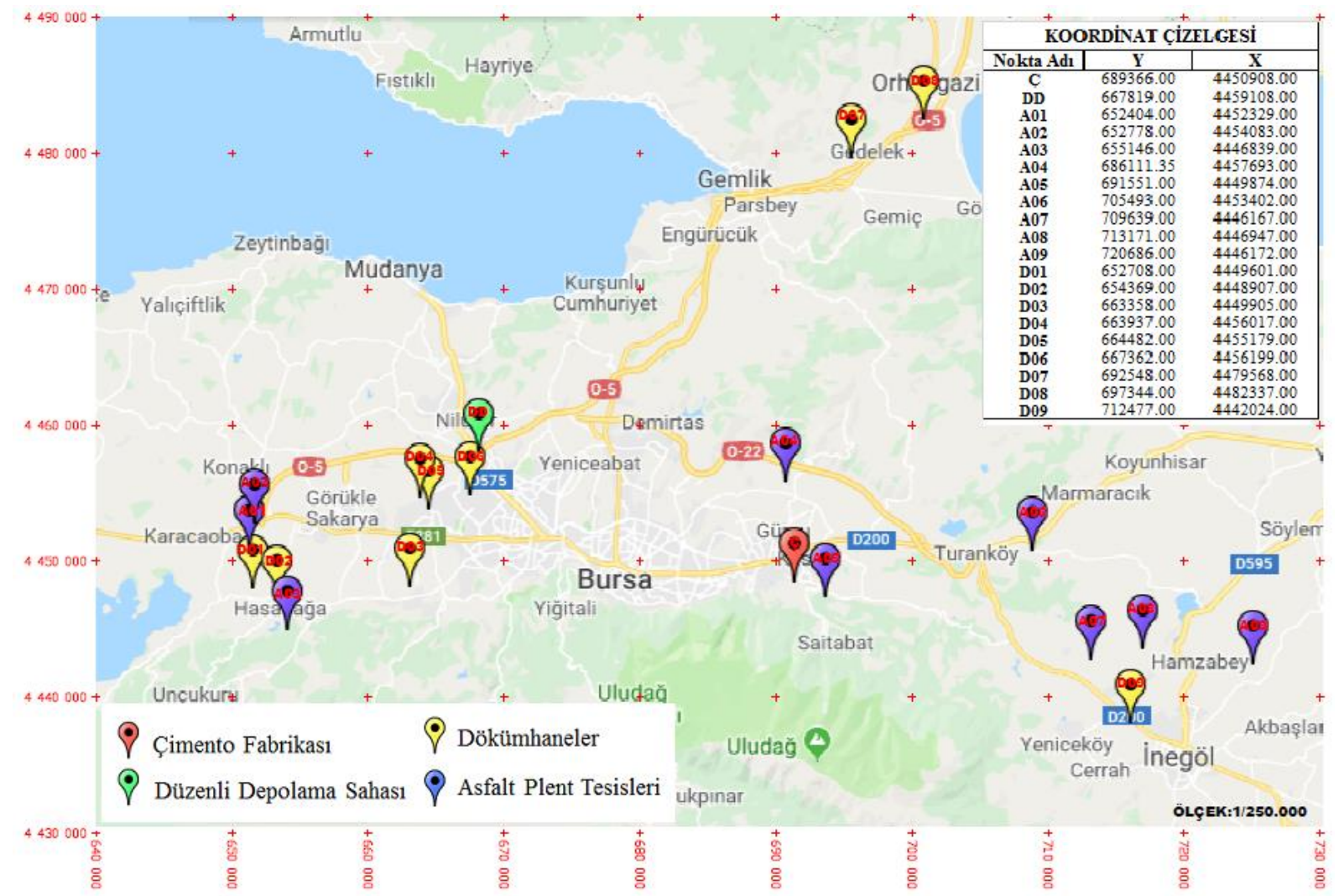

Şekil 1: Bursa ilindeki dökümhaneler, asfalt plent tesisleri, düzenli depolama sahası ve çimento fabrikasının lokasyonu

Asfalt plent tesisleri maden ocaklarından temin edilen farklı boyutlardaki agrega ile diğer bileşenlerin (bitüm vb.) belirli oranlarda karıştırılarak 1sıtıldığı ve sonrasında Şekil 2'de gösterilen aşamalardan geçirilerek asfaltın üretildiği tesislerdir. Asfalt kaplama karışımlarında kullanılan agregalar karışımın ağırlıça \%90-96'sını, hacimce ise \%75-85'ini oluşturmaktadır (Polat 2013). Akbulut ve Gürer (2006) asfalt kaplama yollarda kullanılan malzemelerin ortalama \%95'inin agregalardan oluştuğunu, tüketilen agreganın yol inşaatına yakın maden ocaklarından temin edildiğini ve her geçen gün yeni agrega ocaklarına talebin artması nedeniyle yeryüzünün doğal yapısının bozulduğunu belirtmişlerdir.

Agregalar, temiz, pürüzlü, sağlam ve dayanıklı tanelerden oluşması gerektiğinden (Polat 2013), aynı özelliklere sahip atıkların asfalt üretiminde yapay agrega olarak kullanılması da mümkündür. Aktaş vd. (2011) yaptıkları çalışmada atık shingle parçacıklarının bitümlü sıcak karışım içinde kullanımını test etmişler ve Karayolları Teknik Şartnamesindeki limitler içerisinde kaldığını belirtmişlerdir. Huang vd. (2007) asfalt üretimi içinde cam atıklarının, çelikhane cüruflarının, lastik ve plastik atıkların kullanılabilirliğini ortaya koymuşlardır. Morova ve Terzi (2015) blok halindeki kolemanit malzemenin işlenmesi aşamasında ortaya çıkan atık kolemanitin sıcak karışım asfalt içinde agrega olarak kullanılabileceğini ifade etmişlerdir. Üstünkol ve Turabi (2009) endüstriyel atıkların karayolu üst yapılarında kullanımı ile ilgili yaptıkları çalışmada endüstriyel atık filler malzemelerin (mermer tozu, uçucu kül, fosfo alçı ve cam tozu) bitümlü sıcak karışımlarda \%7 oranında kullanılabileceği sonucuna ulaşmışlardır. Karacasu ve Bilgiç (2009) atık lastik, plastik ve lastik tozlarının asfalt üretimi içerisinde kullanımı ile ilgili yaptıkları çalışmada agrega yerine \%2 oranında kullanılabileceğini belirtmişlerdir.

Atık döküm kumu yapısal olarak mineral bir malzeme olması nedeniyle asfalt üretiminde kullanılan ince agrega ile fiziksel olarak benzerlik göstermektedir (Dyer vd. 2018). Miller vd. (2001) yalnızca agrega kullanılarak standartlara uygun olarak üretilmiş asfalt ile atık döküm kumu kullanılarak üretilen asfalt numuneleri test edildiğinde, asfaltın içinde kullanılacak atık döküm kumunun optimum miktarının \%5-6.2 aralığında olduğunu belirtmişlerdir. Bakış vd. (2006) ise asfalt üretimi için ince agrega yerine atık döküm kumu kullanılarak yapılan testlerde atık döküm kumunun en fazla \%10 oranında kullanılabileceği sonucuna ulaşmışlardır. 


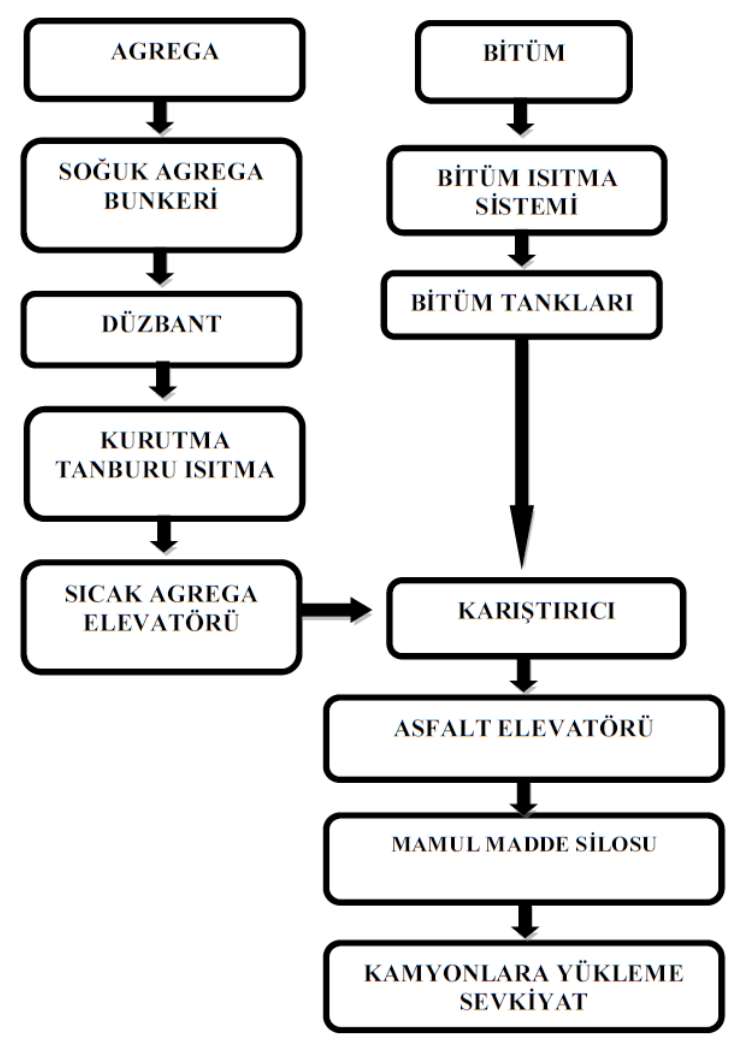

Şekil 2: Asfalt üretimi iş akım şeması

Asfalt üretim prosesi içinde atık döküm kumlarının alternatif hammadde olarak kullanılması, dökümhanelerin atık gönderiminde yaşadıkları sorunları azaltacak, atığın uzak mesafelere taşınmasını durduracak, atıkların biriktirildiği alanda su, hava ve toprak kirliliğine yol açmasını önleyecek ve bertaraf maliyetlerini düşürerek atık döküm kumlarının geri kazanılmasını teşvik edecektir. Hammadde yerine atık döküm kumu kullanımı asfalt plent tesislerinin üretim maliyetlerini azaltarak hammadde tasarrufu sağlayacaktır.

Bu çalışmada, Türkiye'de faaliyet gösteren dökümhanelerden kaynaklanan atık döküm kumlarının bertarafında sürdürülebilir bir atık yönetimi uygulanabilmesi için en uygun yöntem maliyet analizi ile belirlenmeye çalışılmıştır. Bu amaçla, dökümhanelerde 2017 yılında üretilen metal döküm ürünlerine ve asfalt plent tesislerinin asfalt üretim miktarlarına ait veriler ile Çevre ve Şehircilik Bakanlığı'nın yayımladığı Döküm Sektörü Rehber Doküman'dan faydalanılarak, dökümhanelerde bir yılda oluşan atık döküm kumlarının miktarı hesaplanmış ve ülke genelinde oluşan tüm atık döküm kumlarının, düzenli depolama sahası ya da çimento fabrikalarına gönderilmesi yerine asfalt üretiminde kullanılabilmesi için gerekli kullanım yüzdesi belirlenmiştir. Bursa ili genelinde faaliyet gösteren dökümhaneler, çimento fabrikası, düzenli depolama sahası ve asfalt plent tesisleri Şekil 4'te verilen harita üzerinde gösterilmiş, Nilüfer ilçesinden seçilen bir dökümhanede oluşan atık döküm kumunun, düzenli depolama sahasına, çimento fabrikasına ve asfalt plent tesisine gönderilmesi durumları nakliye bedelleri dahil hesaplanarak karşılaştırılmış ve minimum maliyetli atık gönderim seçeneği belirlenmiştir.

\section{Yöntem}

Bu çalışmada, Çevre ve Şehircilik Bakanlığı'nın yayımladığı Döküm Sektörü Rehber Doküman'dan (URL-5 2012) faydalanarak, Bursa ili Nilüfer ilçesinde faaliyet gösteren bir dökümhaneden kaynaklanan atık döküm kumu miktarı hesaplanmış, bu atıkların düzenli depolama sahası ya da çimento fabrikasına gönderilmesi yerine, asfalt plent tesislerinde alternatif hammadde olarak değerlendirilmesi sonucu elde edilecek ekonomik kazanca dayalı maliyet analizi yapılmıştır.

\section{Bulgular}

Atık döküm kumu yapısal olarak mineral bir malzeme olması nedeniyle asfalt üretiminde kullanılan ince agrega ile fiziksel olarak benzerlik göstermektedir (Dyer vd. 2018).1 ton metal döküm üretimi sonrası ortalama 0.35 ton döküm atığg oluştuğu ve bu atığın \%65'nin atık döküm kumu olduğu kabulü (URL-5 2012) ile yıllık metal döküm üretimine göre oluşan atık döküm kumlarının miktarı hesaplanmıştır. 2017 yılında 2.155.000 ton metal döküm ürünü üretilmiştir (URL4 2018). Buna bağlı olarak yalnızca 2017 yılında; 
$2.155 .000 \times 0.35=754.250$ ton döküm atı̆̆ 1 ve

754.250 x $0.65=490.262 .5$ ton (yaklaşık 490.000 ton) atık döküm kumu oluşmuştur.

Türkiye'de son yıllarda İstanbul-İzmir Otoyolu, Osmangazi Köprüsü, Yavuz Sultan Selim Köprüsü, Avrasya Tüneli ve İstanbul Havalimanı gibi önemli ve büyük projelerin hayata geçmesi ile asfalt kullanım miktarlarında da artış olmuştur. Türkiye ve diğer Avrupa ülkelerinin asfalt üretim miktarlarının yıllara göre değişimi Şekil 3'te gösterilmiştir (URL-10 2016). Şekil 3 incelendiğinde, ülkemizde 2014 yılındaki asfalt üretim miktarının bir önceki yıla göre 1/3 oranında düşüş gösterdiği, ilerleyen yıllarda ise yeniden artışa geçerek son altı yılın ortalamasına ulaşıldığı ve 2016 yılında 40,4 milyon ton asfalt üretildiği görülmektedir. 2010-2016 yılları arasında yapılan asfalt üretim miktarlarına göre, Almanya 296 milyon ton üretim ile Avrupa'da ilk sırada yer alırken, Türkiye 280,4 milyon ton ile Almanya'nın ardından Avrupa'da ikinci sırada bulunmaktadır. Son 7 yıl içerisinde Almanya'da bir yılda en fazla 50 milyon ton asfalt üretilmişken, Türkiye'de bu rakam 46,2 milyon ton'dur.

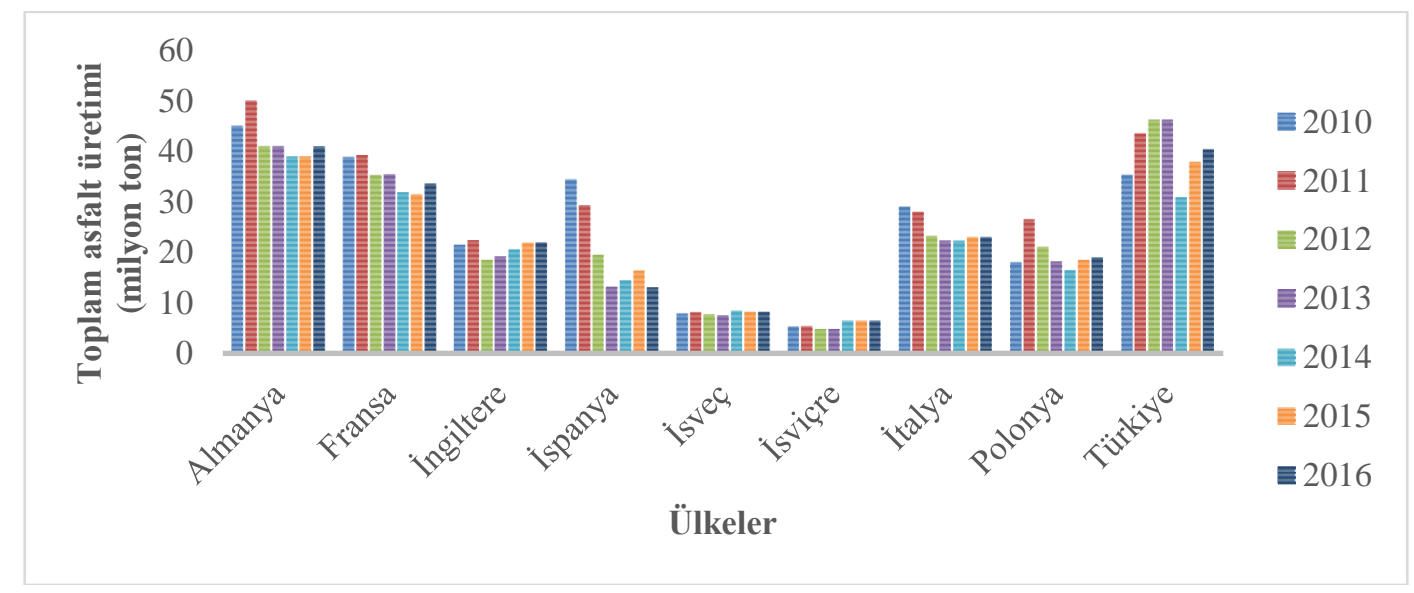

Şekil 3: Yıllara göre Türkiye ve Avrupa'daki asfalt üretim miktarları

Ülkemizde 2016 yılında 40.400.000 ton asfalt üretimi yapılmıştır (URL-10 2016). 2017 yılında 2.155.000 ton metal döküm ürünü üretilmiştir (URL-4 2018). 2017 yılında metal döküm üretimi sonucu 490.000 ton atık döküm kumu oluştuğu hesaplanmıştır. Ülke genelinde asfalt üretiminde agrega yerine atık döküm kumu kullanım oranı;

$490.000 / 40.400 .000 \times 100=\% 1.21$ olmalidir.

Asfalt üretimi içinde ince agrega yerine atık döküm kumunun en fazla \%10 oranında kullanılabileceğinden yola çıkılarak (Bakış vd. 2006), Türkiye'de 2017 yılında oluşan atık döküm kumu, ülke genelinde asfalt üretimi içinde agrega yerine \%1,21 oranında kullanıldığında bir yılda oluşacak tüm atık döküm kumları tüketilmiş olacaktır. Bursa ili Nilüfer ilçesinde faaliyet gösteren dökümhanelerden birinin y1llık metal döküm üretim kapasitesi 46.200 ton'dur (URL-11 2018).

Y1ll1k oluşan atık miktarı 46.200 ton x $0.35=16.170$ ton,

Yıllık oluşan atık döküm kumu miktarı ise; 16.170 ton x $0.65=10.510$ ton olarak hesaplanmaktadır.

Şekil 4'te gösterildiği gibi, Nilüfer ilçesindeki dökümhaneye 19 km uzaklıkta, yıllık asfalt üretim kapasitesi 576.000 ton olan asfalt plent tesisi bulunmaktadır (URL-12 2015). Dökümhanede oluşan 10.510 ton atık döküm kumlarının asfalt plent tesisinde alternatif hammadde olarak agrega yerine kullanılması durumunda dökümhane ve asfalt plent tesisi arasında endüstriyel simbiyoz kurulmuş olacaktır. Bu durumda dökümhane atık döküm kumlarını geri kazanıma gönderecek, asfalt plent tesisi ise hammadde olarak kullanacağı agrega miktarını azaltarak hammaddeden kar elde edecektir. Bursa ilindeki bir dökümhanenin yıllık atık döküm kumu miktarı 10.510 ton'dur. Bir asfalt plent tesisinin üretim kapasitesi 576.000 ton'dur. Nilüfer ilçesindeki asfalt plent tesisinde agrega yerine atık döküm kumu kullanım oran1;

$(10.510 / 576.000) \times 100=\% 1.83$ olmalıdır

Nilüfer ilçesindeki dökümhanede oluşan 10.510 ton atık döküm kumunun fabrikaya $19 \mathrm{~km}$ uzaklıktaki asfalt plent tesisinde asfalt üretimi içinde agrega yerine \%1.83 oranında kullanılması durumunda bir yılda oluşacak tüm atık döküm kumları tüketilmiş olacaktır. Bu hesaplamadan asfalt plent tesisi kapasitesinin yeterli olduğu görülmektedir. 


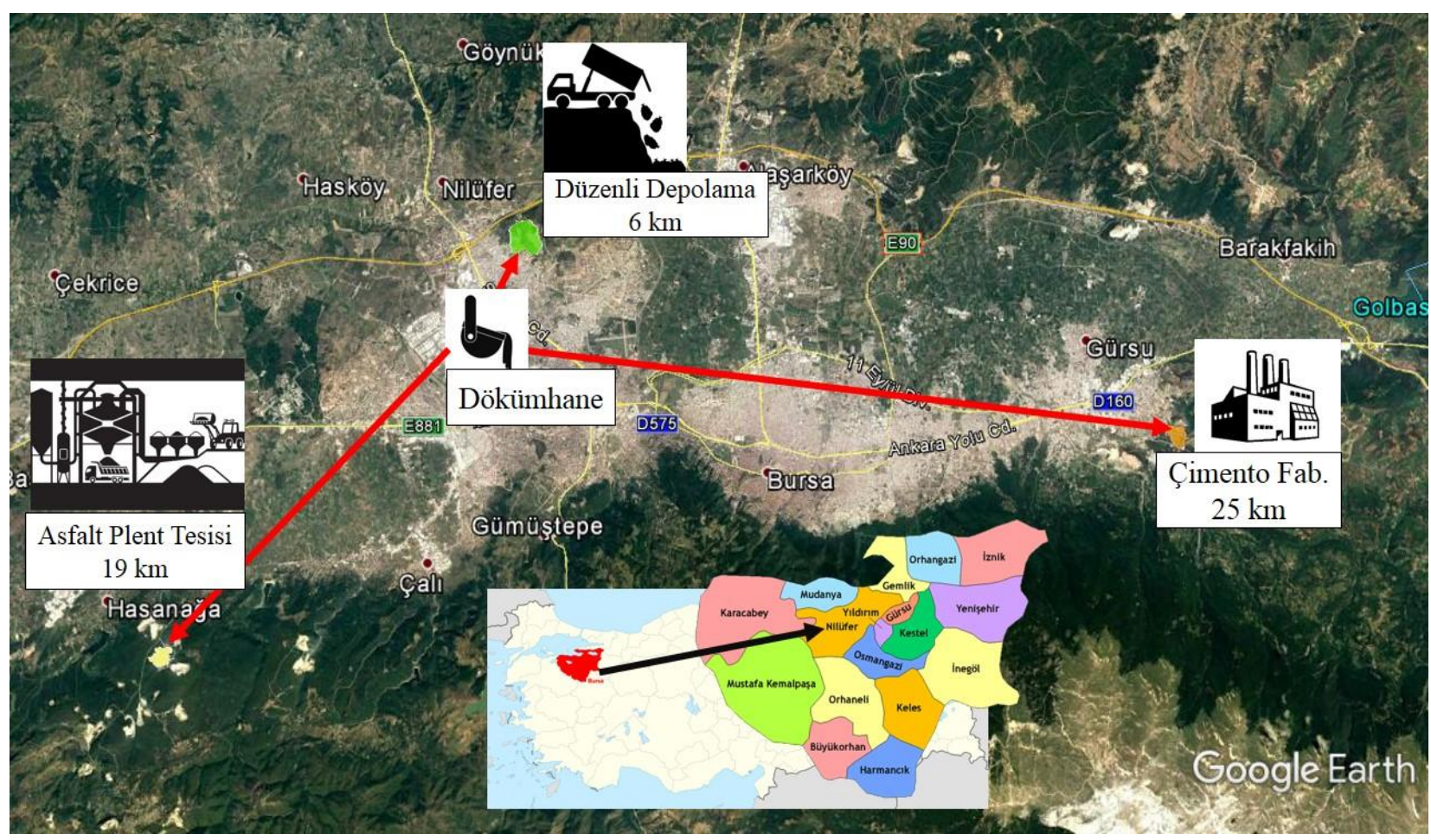

Şekil 4: Bursa ili Nilüfer ilçesindeki dökümhanenin atık bertaraf yerlerine uzaklığı

Atık döküm kumlarının asfalt plent tesisine gönderilmesi:

Dökümhanede 1 yılda oluşan 10.510 ton atık döküm kumunun asfalt plent tesisine geri kazanılmak üzere bedelsiz gönderileceği, asfalt plent tesisinin atık döküm kumlarını hammadde olarak kullanacağı göz önünde bulundurularak;

- Dökümhanenin atık döküm kumu bertaraf maliyeti 10.510 ton $\times 0 \mathrm{TL} / \mathrm{ton}=0 \mathrm{TL}(0 \$)$

Dökümhanede oluşan 10.510 ton atık döküm kumlarının nakliyesi için $19 \mathrm{~km}$ uzaklıktaki asfalt plent tesisine 25 ton taşıma kapasiteli araçlar ile 10.510 ton / 25 ton/sefer $=420$ sefer yapılması gerekmektedir. Araçların bir seferde gidişdönüş 38 km yol yapacağı ve 1 km'de 2,2 TL ( 0.42 \$) akaryakıt kullanacağı hesaplanarak;

- Dökümhanenin atık taşıma maliyeti

$38 \mathrm{~km} / \mathrm{sefer} \times 2.22 \mathrm{TL} / \mathrm{km}=84.36 \mathrm{TL} / \mathrm{sefer}$

$84.36 \mathrm{TL} / \mathrm{sefer} \times 420$ sefer $=35.431 \mathrm{TL}(6.814 \$)$

Atık döküm kumlarının çimento fabrikasına gönderilmesi:

Dökümhanede 1 yılda oluşan 10.510 ton atık döküm kumunun, ton başına 100 TL (19.23 \$) bedel ödeyerek çimento fabrikasına gönderilmesi ve burada klinker üretiminde alternatif hammadde olarak kullanılacağı göz önünde bulundurularak;

- Dökümhanenin atık döküm kumu bertaraf maliyeti 10.510 ton $\times 100 \mathrm{TL} / \mathrm{ton}=1.051 .000 \mathrm{TL}(202.115 \$)$

Dökümhanede oluşan 10.510 ton atık döküm kumunun nakliyesi için $25 \mathrm{~km}$ uzaklıktaki çimento fabrikasına 25 ton taşıma kapasiteli araçlar ile 10.510 ton $/ 25$ ton/sefer $=420$ sefer yapılması gerekmektedir. Araçların bir seferde gidişdönüs 50 km yol yapacağı ve 1 km'de 2,2 TL (0.42 \$) akaryakıt kullanacağı hesaplanarak;

- Dökümhanenin atık taşıma maliyeti

$50 \mathrm{~km} / \mathrm{sefer} \times 2.22 \mathrm{TL} / \mathrm{km}=111 \mathrm{TL} / \mathrm{sefer}$

$111 \mathrm{TL} / \mathrm{sefer} \times 420 \mathrm{sefer}=46.620 \mathrm{TL}(8.965 \$)$ 
$\underline{\text { Atık döküm kumlarının düzenli depolama tesisine gönderilmesi: }}$

Bursa Büyükşehir Belediyesi Düzenli Katı Atık Depolama tesisinde, 1 ton tehlikesiz atık döküm kumu 80 TL (15.39 \$) (URL-13 2018) karşılığında bertaraf edilmektedir. Dökümhanede 1 yılda oluşan 10.510 ton atık döküm kumunun, ton başına 80 TL (15.39 \$) bedel ödeyerek, belediyenin düzenli depolama tesisine bertaraf edilmek üzere gönderilmesi durumunda;

- Dökümhanenin atık döküm kumu bertaraf maliyeti 10.510 ton $\mathrm{x} 80 \mathrm{TL} / \mathrm{ton}=840.800 \mathrm{TL}(161.692 \$)$

Dökümhanede oluşan 10.510 ton atık döküm kumunun nakliyesi için $6 \mathrm{~km}$ uzaklıktaki düzenli depolama tesisine 25 ton taşıma kapasiteli araçlar ile 10.510 ton / 25 ton/sefer $=420$ sefer yapılması gerekmektedir. Araçların bir seferde gidişdönüş 12 km yol yapacağı ve 1 km’de 2,2 TL (0.42 \$) akaryakıt kullanacağı hesaplanarak;

- Dökümhanenin atık taşıma maliyeti $12 \mathrm{~km} / \mathrm{sefer} \times 2.22 \mathrm{TL} / \mathrm{km}=26.64 \mathrm{TL} / \mathrm{sefer}$ $26.64 \mathrm{TL} / \mathrm{sefer} \mathrm{x} 420$ sefer $=11.189 \mathrm{TL}(2.152 \$)$

Dökümhanede oluşan 10.510 ton atık döküm kumunun asfalt plent tesisi, çimento fabrikası ve düzenli depolama tesisine olan mesafeleri de göz önünde bulundurularak yapılan bertaraf maliyeti hesabı Tablo 1' de verilmiştir.

Tablo 1. Atık döküm kumu bertaraf ve taşıma maliyetleri

\begin{tabular}{ccccccc}
\hline \multirow{2}{*}{ Dökümhanenin } & \multicolumn{2}{c}{ Asfalt Plent Tesisi } & \multicolumn{2}{c}{ Düzenli Depolama Tesisi } & \multicolumn{2}{c}{ Çimento Fabrikası } \\
\cline { 2 - 7 } & $\mathrm{TL}$ & $\$$ & $\mathrm{TL}$ & $\$$ & $\mathrm{TL}$ & $\$$ \\
\hline Atık Bertaraf Maliyeti & 0 & 0 & 840.800 & 161.692 & 1.051 .000 & 202.115 \\
\hline Atık Taşıma Maliyeti & 35.431 & 6.814 & 11.189 & 2.152 & 46.620 & 8.965 \\
\hline Toplam Maliyet & 35.431 & 6.814 & 851.989 & 163.844 & 1.097 .620 & 211.081 \\
\hline${ }^{*}: 1 \$=5.20$ TL alınmıștır. & & & &
\end{tabular}

Dökümhanenin atık döküm kumlarını düzenli depolama tesisine göndererek bertaraf ettirmek yerine, asfalt plent tesisine göndermesi atık bertaraf maliyetleri açısından kar etmesini sağlayacaktır.

- Dökümhanenin elde edeceği kar miktarı $851.989-35.431=816.558$ TL $(157.030 \$)$

Dökümhanenin atık döküm kumlarını çimento fabrikasına göndererek bertaraf ettirmek yerine, asfalt plent tesisine göndermesi atık bertaraf maliyetleri açısından kar etmesini sağlayacaktır.

- Dökümhanenin elde edeceği kar miktarı $1.097 .620-35.431=1.062 .189$ TL $(204.267 \$)$

Dökümhanenin asfalt plent tesisi, çimento fabrikası ve düzenli depolama tesisine atık göndermesi durumunda karşılaması gereken toplam maliyet ve kar/zarar grafiği Şekil 5'tegösterilmiştir. Dökümhanede yılda oluşan 10.510 ton atık döküm kumunun asfalt plent tesisi, düzenli depolama sahası ve çimento fabrikasına gönderim maliyetleri sirasıyla 35.431 TL (6.814 \$), 851.989 TL (163.844 \$) ve 1.097.620 TL (211.081 \$)'dir. Atık döküm kumları düzenli depolama tesisi yerine asfalt plent tesisine gönderildiğinde $816.558 \mathrm{TL}(157.030$ \$), çimento fabrikası yerine asfalt plent tesisine gönderildiğinde ise 1.062.189 TL (204.267 \$) kar elde edilecektir. Tam tersi durumlarda ise dökümhane aynı miktarlarda zarara uğrayacaktır. 


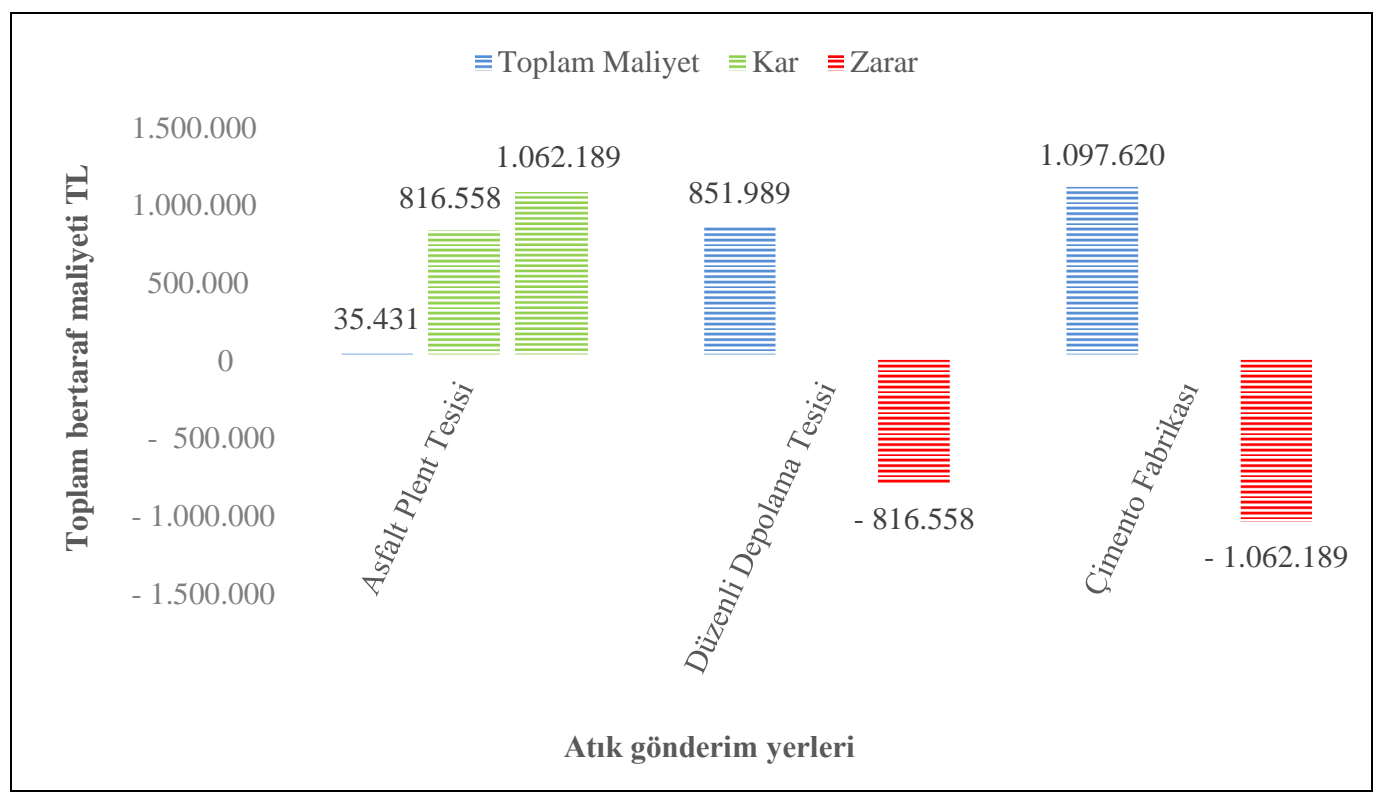

Şekil 5: Dökümhanenin atık gönderim yerlerine göre kar zarar grafiği

Asfalt plent tesisi, atık döküm kumlarını hammadde olarak kullanacağından dökümhane ile arasında kurulacak endüstriyel simbiyoz ile 10.510 ton agrega tasarruf etmiş olacaktır. 1 ton agrega fiyatının 25 TL (4.81 \$) (URL-14 2018) olduğu göz önünde bulundurularak;

- Asfalt plent tesisinin agrega alımı için ödeyeceği bedel ya da atık döküm kumu kullanarak elde edeceği kar 10.510 ton $\times 25 \mathrm{TL} /$ ton $=262.750 \mathrm{TL}(50.529 \$)$

Nilüfer ilçesindeki dökümhanede yılda 10.510 ton atık döküm kumu oluşmaktadır. Tehlikesiz atıklar oluştuğu tarihten itibaren mevzuat gereği en fazla 1 yıl geçici depolanabildiğinden (URL-15 2011), atık bertaraf maliyetlerinin yüksek olması nedeniyle tesis dışına gönderilmediğinde;

- Fabrika sahasında depolanacak atık döküm kumu miktarı 10.510 ton'dur.

İşletmeler, Pazar ve yıllık resmi tatil günleri çıkarıldığında ortalama 300 gün çalışmakta olup, dökümhanede günlük oluşacak ve biriktirilecek atık döküm kumu miktarı;

- $(10.510$ ton/y1l $) /(300 \mathrm{gün} / \mathrm{y} 11)=35$ ton olacaktır.

Dökümhane yakınında faaliyet gösteren asfalt plent tesisi ile kurulacak endüstriyel simbiyoz ilişkisi ile günlük 35 ton atık döküm kumu asfalt üretimi içerisinde kullanılabilecek olup, böylelikle atık döküm kumlarının fabrika sahası içinde 10.510 ton yerine 35 ton olarak biriktirilmesinden kaynaklı oluşabilecek çevresel etkiler en aza indirilmiş ve henüz hava, su ve toprak kirliliği oluşmadan önlenmiş olacaktır.

\section{Sonuçlar}

Atıkların geri kazanılması ve endüstriyel simbiyoz ile üretimde yeniden kullanılması çevre için oldukça önemlidir. ArGe çalışmaları ve atıkların üretim prosesleri içinde denenmesi ile birçok farklı atık türü değerlendirilmeye çalışılmaktadır. Özellikle proses gereği sürekli ve yüksek miktarda oluşan endüstriyel atıkların geri dönüşüm ve geri kazanım süreci içinde değerlendirilmesi hem maddesel hem de enerji olarak kazanç sağlamaktadır. Atıkların depolanması geçici ve eski bir çözüm olup, atık hiyerarşisi içinde en son başvurulması gereken yöntemlerdendir.

Yerel yönetimler vahşi depolama sahalarını rehabilite ederek, şehirlerde oluşan tüm evsel atıkları düzenli depolama tesislerine taşımaktadırlar. Düzenli depolama sahalarının kapasiteleri burada önemli rol oynamakta olup, değerlendirilebilecek atıkların düzenli depolama sahalarına gönderilmesi, bu sahaların kapasitelerinin erkenden dolmasına ve ekonomik ömürlerini yitirmelerine neden olmaktadır. 
$\mathrm{Bu}$ çalışma kapsamında, Bursa ilinin Nilüfer ilçesinde faaliyet gösteren bir dökümhanede bir yılda oluşan atık döküm kumlarının, düzenli depolama tesisi ve çimento fabrikasına gönderilmesi yerine, asfalt plent tesislerinde agrega yerine alternatif hammadde olarak kullanılması sonucu elde edilecek ekonomik fayda ile dökümhanenin atık bertaraf maliyeti hesaplanmış ve elde edilen sonuçlar aşağıda verilmiştir:

- Ülkemizde bir yılda oluşan atık döküm kumu miktarı 490.000 ton olarak hesaplanmış olup, bu atıkların ülke genelinde asfalt üretimi yapan tesislerde alternatif hammadde olarak \%1.21 oranında kullanılması tüm atık döküm kumlarının geri kazanımı için yeterli bulunmuştur.

- Nilüfer ilçesindeki dökümhaneden bir yılda oluşacak 10.510 ton atık döküm kumunun, aynı ilçedeki asfalt plent tesisinin üretim prosesinde yalnızca \%1,83 oranında kullanılması sonucunda bir yılda oluşacak tüm atık döküm kumlarının bertarafi için yeterli olduğu belirlenmiştir.

- Nilüfer ilçesindeki dökümhanede oluşan atık döküm kumlarının çimento fabrikasına, düzenli depolama sahasına ve asfalt plent tesisine gönderimi için nakliye dahil ödenmesi gereken toplam bedel sırasıyla,1.097.620 TL (211.081 \$), 851.989 TL (163.844 \$) ve 35.431 TL (6.814 \$) olarak hesaplanmıştır.

- Endüstriyel simbiyoz ile asfalt plent tesisinde asfalt üretiminde kullanılacak atık döküm kumları için ayrıca bir bertaraf maliyeti oluşmayacak, düzenli depolama tesisine ödenecek bedel kadar dökümhane kar elde etmiş olacaktır. Dökümhane yalnızca atığın nakliyesi için 35.431 TL (6.814 \$) bedel ödeyecek olup, düzenli depolama tesisine gönderim ile karşılaştırıldığında yılda 816.558 TL (157.030 \$),çimento fabrikasına gönderim ile karşılaştırıldığında ise 1.062.189 TL (204.267 \$) kar elde etmiş olacaktır (Şekil 5).

- Dökümhanede oluşan atık döküm kumlarının agrega olarak asfalt üretiminde kullanılması ile asfalt plent tesisi 10.510 ton hammaddeye ödeyeceği 262.750 TL (50.529 \$) bedel kadar kar elde edecektir.

Ülkemizde atık döküm kumlarının alternatif hammadde olarak kullanımı yalnızca çimento fabrikalarında mümkün olduğundan, atık döküm kumlarının diğer sektörlerde kullanımı konusunda yapılan çalışma sayısının arttırılması asfalt üretimi yapan tesisler için faydalı olacaktır. Dökümhaneler ile asfalt plent tesisleri arasındaki mesafe çimento fabrikalarına göre daha az olduğundan atığın daha az taşınması, en hızlı şekilde geri kazanılması, karbondioksit salınımı ve sera gazlarının azaltımı için de çevreci bir yaklaşım olacaktır. Atık döküm kumlarının alternatif hammadde olarak asfalt üretiminde kullanılabilmesi için ülkemizde yetkili merci olan Çevre ve Şehircilik Bakanlığı'nca yapılacak mevzuat düzenlemesinin endüstriyel simbiyoz uygulamalarını teşvik edeceği ve diğer atıklar için de öncü olacağı düşünülmektedir.

\section{Kaynaklar}

Akbulut H., Gürer C., (2006), Atık mermerlerin asfalt kaplamalarda agrega olarak değerlendirilmesi, İMO Teknik Dergi, 261, $3943-$ 3960.

Aktaş B., Karaşahin M., Gürer C., Uz V.E., (2011), Shingle atıklarının asfalt betonu kaplamalar içerisinde kullanımının araștırılması, e-Journal of New World Sciences Acamedy, 6, 1306-3111.

Apay A.C., Özkan Ö., Yılmaz C., (2011), Alternatifyakıt ürünlerinin klinker üretiminde kullanımına bir örnek: Akçansa Büyükçekmece Çimento Fabrikası, New World Sciences Academy, 6(4), 1306-3111.

Bakış R., Koyuncu H., Demirbaş Y., (2006), An investigation of waste foundry sand in asphalt concrete mixtures, Waste Management \& Research, 24, 269-274.

Çoban Z., (2016), Endüstriyel simbiyoz ve uygulamalarl, Bitirme Tezi, Ondokuz Mayis Üniversitesi, Samsun.

Dyer P.P.O.L., Geimba de Lima M., Klinsky L.M.G., Silva S.A., Coppio G.J.L., (2018), Environmental characterization of foundry waste sand (WFS) in hot mix, Construction and Building Materials, 171, 474-484.

Gedik A., (2008), Utilization of waste foundry sand as highway material, Yüksek Lisans Tezi, İstanbul Teknik Üniversitesi, İstanbul.

Huang Y., Bird R.N., Heidrich O., (2007), A review of the use of recycled solid waste materials in asphalt pavements, Resources Conservation and Recycling, 52, 58-73.

Karacasu M., Bilgiç Ş., (2009), Atık lastik katkısının sıcak asfalt özelliklerine etkisi, ESOGÜ Mühendislik Mimarlık Fakültesi Dergisi, 22(2), 45-64.

Khatib J.M., Herki B.A., Kenai S., (2013), Capillarity of concrete incorporating waste foundry sand, Construction and Building Materials, 47, 867-871.

Miller E., Bahia H.U., Benson C., Khatri A., Braham A., (2001), Utilization of waste foundry sand in hot mix asphalt mixtures, AFS Transactions, 1(103), 1-15.

Morova N., Terzi S., (2015), Kolemanit atıkların sıcak karışım asfalt betonda agrega olarak değerlendirilmesi, Süleyman Demirel Üniversitesi Fen Bilimleri Enstitüsü Dergisi, 19(2), 8-15.

Polat M.Ö., (2013), Bitümlü sıcak karışımların çevresel yaşam döngüsü analizi, Yüksek Lisans Tezi, Gebze İleri Teknoloji Enstitüsü, Kocaeli.

URL-1 (2010), Toprak Kirliliğinin Kontrolü ve Noktasal Kaynaklı Kirlenmiş Sahalara Dair Yönetmelik, R.G. Tarihi: 08.06.2010, R.G. Sayısı:27605, Çevre ve Şehircilik Bakanlı̆̆1, Ankara. http://www.mevzuat.gov.tr/Metin.Aspx?MevzuatKod=7.5.14026\& MevzuatIliski=0\&sourceXmlSearch=, [Erişim 04 Ekim 2018].

URL-2, (2017), Sifir Atık Kitapçı̆̆l, Çevre ve Şehircilik Bakanlığı, Ankara. http://webdosya.csb.gov.tr/db/sifiratik/menu/kitapcik_ 20180604103105.pdf, [Erişim 20 Ekim 2018].

URL-3, (2017), Türkiye'nin 500 büyük sanayi kuruluşu, http://www.iso500.org.tr/500-buyuk-sanayi-kurulusu/2017/, [Erişim 05 Kasım 2018].

URL-4, (2018), Türkdöküm, Türkiye Döküm Sanayicileri Derneği, İstanbul. http://tudoksad.org.tr/upload/files/tu\%CC\%88rkdo\%CC $\% 88 \mathrm{ku} \% \mathrm{CC} \% 88 \mathrm{~m} \_47$ _web.pdf, [Erişim 11 Kasım 2018]. 
URL-5, (2012), Türkiye'de Sanayiden Kaynaklanan Tehlikeli Atıkların Yönetiminin Iyileştirilmesi Döküm Sektörü Rehber Doküman, Çevre ve Şehircilik Bakanlığı, Ankara, https://webdosya.csb.gov.tr/csb/dokumanlar/cygm0034.pdf, [Erişim 05 Kasım 2018].

URL-6, (2018), Bursa Ticaret ve Sanayi Odasi, Bursa. http://www.btso.org.tr/?page=members/members.asp, [Erişim 12 Kasım 2018].

URL-7, (2018), Çevre ve Şehircilik Bakanlığg, Ankara. https://eizin.cevre.gov.tr/Rapor/BelgeArama.aspx, [Erişim 12 Kasım 2018 ].

URL-8, (2015), Atık Yönetimi Yönetmeliği, R.G. Tarihi: 02.04.2015, R.G. Sayısı:29314, Çevre ve Şehircilik Bakanlı̆̆ı, Ankara, http://www.resmigazete.gov.tr/eskiler/2015/04/20150402-2.htm, [Erișim 04 Ekim 2018].

URL-9, (2002), Beneficial Reuse of Foundry Sands: A Review of State Practices and Regulations, Sector Strategies Division Office of Policy, Economics, and Innovation, U.S. Environmental Protection Agency, Washington DC. https://nepis.epa.gov/Exe/ ZyNET.exe/9101ZMM6.TXT, [Erişim 13 Kasım 2018].

URL-10, (2016), Asphalt in Figures 2016, European Asphalt Pavement Association, Belçika. https://eapa.org/wp-content/uploads/ 2018/07/2016.pdf, [Erişim 17 Ekim 2018].

URL-11, (2018), Bursa Çevre ve Şehircilik İl Müdürlüğü, Bursa. http://bursa.csb.gov.tr/quot-ced-gerekli-degildir-quot-ilani-duyuru2461, [Erişim 29 Ekim 2018].

URL-12, (2015), 240 ton/saat Kapasiteli Asfalt Plent Tesisi Proje Tanıtım Dosyası, BURÇED, Bursa, http://eced.csb.gov.tr/, [Erişim 31 Ocak 2015].

URL-13, (2018), 2018 Yılı Mali Gelir Tarifesi, Bursa Büyükşehir Belediyesi, Bursa. https://www.bursa.bel.tr/dosyalar/birimek/ 180803111155_Gelir-Tarifesi_03.08.2018.pdf, [Erişim 29 Ekim 2018].

URL-14, (2018), https://yekmaden.com/, [Erişim 26 Ekim 2018].

URL-15, (2011), Bazı Tehlikesiz Atıkların Geri Kazanımı Tebliği, R.G. Tarihi: 17.06.2011, R.G. Sayısı:27967, Çevre ve Şehircilik Bakanlığı, Ankara, http://www.resmigazete.gov.tr/eskiler/2011/06/20110617-9.htm, [Erişim 04 Ekim 2018].

Üstünkol F.M., Turabi A., (2009), Endüstriyel atıkların karayolu üstyapısında değerlendirilmesi, Balıkesir Üniversitesi Fen Bilimleri Enstitüsü Dergisi, 11(1), 15-27.

Yazoghli-Marzouk O., Vulcano-greullet N., Cantegrit L., Friteyre L., Jullien A., (2014), Recycling foundry sand in road constructionfield assessment, Construction and Building Materials, 61, 69-78. 